\title{
Cheese quality from cows given a tannin extract in 2 different grazing seasons
}

\author{
R. Menci, ${ }^{1} \odot$ A. Natalello, ${ }^{1 *}$ ๑ G. Luciano, ${ }^{1}$ A. Priolo, ${ }^{1}$ B. Valenti, ${ }^{2}$ A. Difalco, ${ }^{3}$ T. Rapisarda, ${ }^{3}$ M. Caccamo, ${ }^{3}$ () \\ I. Constant, ${ }^{4}$ V. Niderkorn, ${ }^{4}$ (i) and M. Coppa ${ }^{5}$ (B) \\ ${ }^{1}$ Department Di3A, University of Catania, via Valdisavoia 5, 95123 Catania, Italy \\ ${ }^{2}$ Department DSA3, University of Perugia, Borgo XX Giugno 74, 06121 Perugia, Italy \\ ${ }^{3}$ Consorzio per la Ricerca nel settore della Filiera Lattiero-Casearia e dell'agroalimentare (CoRFiLaC), Regione Siciliana, 97100 Ragusa, Italy \\ ${ }^{4}$ INRAE, Université Clermont Auvergne, Vetagro Sup, UMRH, 63122, Saint-Genès-Champanelle, France \\ ${ }^{5}$ Independent researcher at INRAE, Université Clermont Auvergne, Vetagro Sup, UMRH, 63122, Saint-Genès-Champanelle, France
}

\begin{abstract}
The aim of the present study was to compare the effect of dietary tannins on cow cheese quality in 2 different grazing seasons in the Mediterranean. Two experiments were performed on 14 dairy cows reared in an extensive system. The first experiment took place in the wet season (WS), and the second experiment took place in the dry season (DS). In the WS and DS experiments, cows freely grazed green pasture or dry stubbles, respectively, and the diet was supplemented with pelleted concentrate and hay. In both experiments, the cows were divided into 2 balanced groups: a control group and a group (TAN) receiving $150 \mathrm{~g}$ of tannin extract/head per day. After $23 \mathrm{~d}$ of dietary treatment, individual milk was collected, processed into individual cheeses, and aged 25 d. Milk was analyzed for chemical composition, color parameters, and cheesemaking aptitude (laboratory cheese yield and milk coagulation properties). Cheese was analyzed for chemical composition, proteolysis, color parameters, rheological parameters, fatty acid profile, and odor-active volatile compounds. Data from the WS and DS experiments were statistically analyzed separately with an analysis of covariance model. In the WS experiment, dietary tannin supplementation had no effect on milk and cheese parameters except for a reduced concentration of 2-heptanone in cheese. In the DS experiment, TAN milk showed lower urea N, and TAN cheese had lower C18:1 trans-10 concentration and n-6:n-3 polyunsaturated fatty acid ratio compared with the control group. These differences are likely due to the effect of tannins on rumen $\mathrm{N}$ metabolism and fatty acid biohydrogenation. Dietary tannins may differently affect the quality of cheese from Mediterranean grazing cows according
\end{abstract}

Received February 12, 2021.

Accepted May 1, 2021.

*Corresponding author: antonio.natalello@unict.it to the grazing season. Indeed, tannin bioactivity on rumen metabolism seems to be enhanced during the dry season, when diet is low in protein and rich in acid detergent fiber and lignin. The supplementation dose used in this study ( $1 \%$ of estimated dry matter intake) had no detrimental effects on cheese yield or cheesemaking parameters. Also, it is unlikely that sensorial characteristics would be affected by this kind of dietary tannin supplementation.

Key words: tannin, cheese quality, dairy cow, grazing season

\section{INTRODUCTION}

Tannins are a class of polyphenols found in forages, especially in plant species characterizing marginal areas or dry habitats, and in agricultural by-products (Vasta et al., 2019). Thanks to their antimicrobial and proteinbinding activities, tannins are known to modify ruminal biohydrogenation $(\mathbf{B H})$ and $\mathrm{N}$ metabolism (Patra and Saxena, 2011), with positive consequences on milk and cheese quality. Through the impairing of ruminal BH, dietary tannins are often reported to reduce the SFA content and increase the concentration of PUFA, C18:1 trans-11, and C18:2 cis-9,trans-11 in milk (Frutos et al., 2020). Binding with proteins, tannins can improve the ratio of ruminal protein escape (Waghorn, 2008), increasing both the NAN outflow from the rumen and the EAA concentration of plasma (Min et al., 2002). This could affect cheesemaking properties and cheese quality, as the concentration and type of protein in milk markedly affect cheese yield and its syneretic and rheological characteristics (Guinee, 2003). For instance, dietary chestnut tannin extract was found to increase the casein proportion in ewe milk (Buccioni et al., 2015b) and to delay clotting and firming time (Buccioni et al., 2017).

However, the information available in the literature does not clarify whether and how the effects of dietary 
tannins on cheese quality might vary according to grazing season in extensive farming systems. Indeed, extensive farming systems are characterized by periods with different forage availability during the year because they strictly depend on climatic conditions that allow grazing or not (Ramírez-Rivera et al., 2019). This imbalance in diet during the year has well-known implications for animal performance and product quality. In Mediterranean traditional husbandry, dairy cows have higher milk yield, protein content, and fat content during the green season compared with the dry season (Licitra et al., 1998). In addition, grazing green pasture is reported to increase the content of vitamins and aromatic compounds (Prache et al., 2020) and proportions of PUFA and CLA (Coppa et al., 2019) of milk.

In a recent study, a different response to in vitro rumen $\mathrm{BH}$ and fermentation was observed when 2 different tannin extracts were supplemented to a green forage or a hay substrate (Menci et al., 2021). For instance, both the ratio of C18:2 cis-9,trans-11 to C18:2 cis-9,cis-12 and valerate concentration were lower when tannin extracts were included in the hay substrate. Therefore, we hypothesized that dietary tannins could exert different effects on cow cheese quality and composition when supplemented to a green herbage-based diet or a dry forage-based diet. Thus, the aim of the present study was to compare, for the first time, the effect of dietary tannins on cow cheese quality in 2 different grazing seasons in the Mediterranean. We chose to fit into on-farm conditions to directly test the practical effects of dietary tannin extract supplementation. Previous to this study, the response of some of the parameters analyzed, such as rheology and aromatic compounds, to dietary tannin supplementation had never been investigated.

\section{MATERIALS AND METHODS}

\section{Experimental Design, Animals, and Diets}

All procedures were approved by the animal welfare committee (OPBA) of the University of Catania (UNCTCLE-0015295). Two experiments were conducted in a commercial extensive farm located in the municipality of Ragusa, Italy $\left(36^{\circ} 57^{\prime} \mathrm{N}, 14^{\circ} 40^{\prime} \mathrm{E}\right.$; altitude: $670 \mathrm{~m}$; annual rainfall: $560 \mathrm{~mm}$ ), an upland area of the Mediterranean island of Sicily, Italy. The 2 experiments were carried out in different seasons: the first one was conducted in the wet season (WS), and the second one was conducted in the dry season (DS). The WS experiment was performed in the period between March and April 2019, with a total rainfall of $48.5 \mathrm{~mm}$ and the temperature ranging from 4 to $18^{\circ} \mathrm{C}$ (average temperature: $10^{\circ} \mathrm{C}$ ). The DS experiment was performed in July 2019, with a total rainfall of $1.25 \mathrm{~mm}$ and the temperature ranging from $15^{\circ}$ to $37^{\circ} \mathrm{C}$ (average temperature: $24.5^{\circ} \mathrm{C}$ ).

In both experiments, 14 lactating dairy cows (Modicana breed) were used. On the $2 \mathrm{~d}$ preceding the beginning of both trials, individual milk was sampled and analyzed. Animals were divided into 2 equivalent groups $(\mathrm{n}=7)$ - control $(\mathbf{C O N})$ and tannin $($ TAN $)$ balanced for average milk yield (WS: $11.9 \pm 1.5 \mathrm{~kg} / \mathrm{d}$; DS: $13.6 \pm 2.6 \mathrm{~kg} / \mathrm{d}$ ), protein (WS: $40.2 \pm 1.3 \mathrm{~g} / \mathrm{kg}$; DS: $33.5 \pm 1.6 \mathrm{~g} / \mathrm{kg}$ ), and fat (WS: $39.6 \pm 2.4 \mathrm{~g} / \mathrm{kg}$; DS: $37.2 \pm 3.3 \mathrm{~g} / \mathrm{kg}$ ) contents recorded in these $2 \mathrm{~d}$ as well as DIM (WS: $190 \pm 38$ d; DS: $137 \pm 43 \mathrm{~d}$ ), parity (WS: $4 \pm 1$; DS: $4.2 \pm 1$ ), and BCS (WS: $2.8 \pm 0.2$; DS: $3.6 \pm 0.1)$.

In WS, the cows were free to graze on 20 ha of spontaneous pasture and had free access to drinking water. Thirty botanical species were identified through botanical surveys of the pasture using the vertical point-quadrat method (Daget and Poissonet, 1971). The main botanical species were Bromus hordaeceus L., Medicago polymorpha L., Lolium perenne L., and Anthemis arvensis L. (17, 13, 12, and $11 \%$ on ground cover, respectively). In DS, the cows were free to graze on 20 ha of dry stubble (20-cm harvest cut height because of rocky soil) of an annual crop, composed of vetch (40\%), oat (40\%), and barley (20\%). During the DS experiment, no fresh herbage was available. In both experiments, supplemental pelleted concentrate was individually offered to cows in 2 equal meals just before milking at a rate of 6.4 and $9.6 \mathrm{~kg} / \mathrm{head}$ per day in WS and DS, respectively. Pelleted concentrate was composed of corn grain $(420 \mathrm{~g} / \mathrm{kg})$, soybean meal CP 48\% (250 g/ $\mathrm{kg})$, wheat middlings (100 g/ $\mathrm{kg}$ ), corn flakes $(66 \mathrm{~g} / \mathrm{kg})$, carob germ $(60 \mathrm{~g} / \mathrm{kg})$, carob pods $(30$ $\mathrm{g} / \mathrm{kg})$, beet pulp $(30 \mathrm{~g} / \mathrm{kg})$, rumen-protected fat $(10$ g/kg; Magnapac, Or Sell S.p.a.), $\mathrm{Na}_{2} \mathrm{CO}_{3}(10 \mathrm{~g} / \mathrm{kg})$, $\mathrm{Ca}_{2} \mathrm{CO}_{3}(10 \mathrm{~g} / \mathrm{kg}), \mathrm{NaCl}(8 \mathrm{~g} / \mathrm{kg})$, vitamin and mineral supplement $(4 \mathrm{~g} / \mathrm{kg})$, and urea $(2 \mathrm{~g} / \mathrm{kg})$. In addition, in both experiments cows were individually fed supplemental hay (vetch:oat:barley 40:40:20) during milking in 2 equal meals at a rate of $2 \mathrm{~kg} /$ head per day. Pelleted concentrate and hay were always completely consumed by all the cows. The chemical composition of feedstuffs is shown in Table 1.

In both the WS and DS experiments, the TAN group received $150 \mathrm{~g} /$ head per day of a commercial tannin extract (Silvafeed ByProX, Silvateam), a 60:40 mixture of chestnut (Castanea sativa Mill.) and quebracho (Schinopsis lorentzii Engl.) tannins, included in pelleted concentrate. Total phenolic compound concentration in tannin extract was $688 \mathrm{~g}$ of tannic acid equivalents $/ \mathrm{kg}$ of DM, with $90.2 \%$ of tannins, according to the method 
Table 1. Chemical composition of feeds used in the wet season (WS) and dry season (DS) experiments

\begin{tabular}{|c|c|c|c|c|}
\hline Item & Concentrate & Hay & $\begin{array}{l}\text { Pasture } \\
\text { (only WS) }\end{array}$ & $\begin{array}{c}\text { Stubble } \\
\text { (only DS) }\end{array}$ \\
\hline $\mathrm{DM}, \mathrm{g} / \mathrm{kg}$ & 889 & 833 & 186 & 876 \\
\hline \multicolumn{5}{|c|}{ Chemical composition, $\mathrm{g} / \mathrm{kg}$ of DM } \\
\hline $\mathrm{CP}$ & 200 & 79 & 222 & 69 \\
\hline Ether extract & 36 & 12 & 28 & 11 \\
\hline $\mathrm{NDF}$ & 179 & 708 & 415 & 672 \\
\hline $\mathrm{ADF}$ & 80 & 460 & 269 & 472 \\
\hline ADL & 22 & 62 & 38 & 76 \\
\hline Ash & 51 & 66 & 94 & 67 \\
\hline \multicolumn{5}{|c|}{ Phenolic compounds, g of $\mathrm{TAeq}^{1} / \mathrm{kg}$ of DM } \\
\hline Phenols & 5.2 & 5.2 & 14.2 & 5.4 \\
\hline Tannins & 3.9 & 1.6 & 4.7 & 1.7 \\
\hline \multicolumn{5}{|c|}{ Protein fraction, ${ }^{2} \mathrm{~g} / 100 \mathrm{~g}$ of $\mathrm{CP}$} \\
\hline A & 15.1 & 37.3 & 37.1 & 22.3 \\
\hline B1 & 7.9 & 10.8 & 7.6 & 18.2 \\
\hline B2 & 59.6 & 12.2 & 21.4 & 20.3 \\
\hline B3 & 12.9 & 29.5 & 28.2 & 26.0 \\
\hline $\mathrm{C}$ & 4.5 & 10.1 & 5.8 & 13.1 \\
\hline \multicolumn{5}{|c|}{ Fatty acids, $\mathrm{g} / 100 \mathrm{~g}$ of fatty acids } \\
\hline $\mathrm{C} 16: 0$ & 18.2 & 29.2 & 14.1 & 25.1 \\
\hline C18:0 & 9.2 & 6.0 & 2.4 & 6.2 \\
\hline C18:1 cis-9 & 16.8 & 9.4 & 3.0 & 6.5 \\
\hline C18:2 cis- 9, cis- 12 & 36.2 & 27.0 & 12.1 & 21.1 \\
\hline $\mathrm{C} 18: 3$ cis- 9, cis- 12, cis- 15 & 1.8 & 16.0 & 52.2 & 21.6 \\
\hline
\end{tabular}

${ }^{1}$ TAeq $=$ tannic acid equivalents.

${ }^{2} \mathrm{~A}=\mathrm{NPN} ; \mathrm{B} 1=$ buffer-soluble true protein; $\mathrm{B} 2=$ neutral detergent soluble protein; $\mathrm{B} 3=$ acid detergent soluble protein; $\mathrm{C}=$ acid detergent insoluble protein.

of Makkar et al. (1993). The estimated intake of tannin extract corresponded to $1 \%$ of expected DMI based on the potential intake capacity of experimental cows, according to INRA (2018). The feeding trials lasted $23 \mathrm{~d}$.

\section{Feedstuff Sampling and Analyses}

During the WS and DS experiments, samples of concentrates, hay, pasture, and dry stubble were collected weekly, vacuum packed, and stored at $-20^{\circ} \mathrm{C}$. For the analyses, the weekly subsamples were pooled to get a representative sample of each feed.

Ether extract, CP, and ash were determined according to AOAC International (1995) methods 920.39, 976.06, and 942.05, respectively. Protein fractions were calculated according to the Cornell Net Carbohydrate and Protein System, as modified by Licitra et al. (1996). The analyses of NDF, ADF, and ADL were performed following the method of Van Soest et al. (1991). Total phenolic compounds and total tannins were analyzed according to the procedure of Makkar et al. (1993) with some modification, as reported by Luciano et al. (2019). Fatty acid (FA) profile of feeds was determined through a 1-step extraction-transesterification with chloroform and sulfuric acid (2\% in methanol, vol/vol) as methylation reagent (Valenti et al., 2018). Fatty acid methyl ester separation and quantification was performed using a Thermo Finnigan Trace gas chromatograph equipped with a flame ionization detector (ThermoQuest) and 100-m high-polar fused silica capillary column (SP2560 fused silica, Supelco; 0.25-mm i.d., 0.25- $\mu \mathrm{m}$ film thickness). Helium was used as carrier gas at a constant flow of $1 \mathrm{~mL} / \mathrm{min}$. Oven, injector, and detector were set as described by Natalello et al. (2019). Identification of individual FAME was based on comparison with the retention time of commercially available standard FAME mixtures (Nu-Chek Prep Inc., Larodan Fine Chemicals). Individual FA were expressed as grams per 100 grams of total FA.

\section{Cheesemaking}

In both the WS and DS experiments, 2 cheesemaking sessions were performed, one the day before the beginning of the trial and the other after $23 \mathrm{~d}$ of dietary treatment. For each cheesemaking session, 1 pressed and cooked curd cheese (Canestrato type) was made with the individual milk of each experimental cow, for a total of 14 cheeses in each session and 28 cheeses in each experiment. At cheesemaking, individual raw whole milk from the morning milking was pooled with the corresponding refrigerated raw whole milk from the previous evening milking based on individual milk yield. Then, $7 \mathrm{~kg}$ of individual raw whole milk was heated 
in a water bath to reach the optimal temperature for coagulation $\left(38-39^{\circ} \mathrm{C}\right)$. A commercial liquid veal rennet $[105$ international milk clotting units (IMCU)/ $\mathrm{mL}, 80 \%$ chymosin and $20 \%$ pepsin; Biotec Fermenti s.r.l.] was then added to get a final concentration of $37 \mathrm{IMCU} / \mathrm{L}$, following manufacturer recommendation. One hour later, the curd was cut to a size of 5 to 10 $\mathrm{mm}$, and $1.2 \mathrm{~L}$ of water at $75^{\circ} \mathrm{C}$ was added for curd cooking. Curd was precipitated for $10 \mathrm{~min}$, transferred to a basin, and pressed to remove excess whey. After 20 min of forming, with continuous turning of the curd, a second cooking was carried out by diving forms into $5 \mathrm{~L}$ of hot water $\left(75-80^{\circ} \mathrm{C}\right)$ for $1 \mathrm{~h}$. Cheeses were then immersed in saturated brine $\left(23^{\circ} \mathrm{Bé} ; 300 \mathrm{~g} / \mathrm{L} \mathrm{NaCl}\right)$ at $10^{\circ} \mathrm{C}$ for $2 \mathrm{~h}$. After brining, cheeses were aged in a ripening cellar for $25 \mathrm{~d}$ at $10^{\circ} \mathrm{C}$ and $80 \%$ relative humidity. Clotting time and $\mathrm{pH}$ were monitored during each cheesemaking step. Weight of cheese was recorded before and after brining and weekly during aging.

\section{Milk Sampling and Analyses}

Aliquots of the individual milk used for cheesemaking were stored at $-20^{\circ} \mathrm{C}$ pending $\mathrm{Ca}$ determination or immediately processed for determination of proximate composition, SCC, color parameters, laboratory cheese yield, and milk coagulation properties. Fat, lactose, and protein contents in milk and MUN were analyzed with a Milkoscan FT 1 (Foss) according to ISO 9622 (ISO, 2013). On the same aliquot, SCC was determined using a BacSomatic (Foss) according to ISO 13366-2 (ISO, 2006). Calcium content in milk was quantified by back titration with EDTA of ashes (Kindstedt and Kosikowski, 1985).

Milk color parameters in the CIE $\mathrm{L}^{*} \mathrm{a} * \mathrm{~b}$ space were measured using a Minolta CM-2022 portable spectrophotometer (d/8 geometry; Minolta Co. Ltd.) using illuminant $\mathrm{A}$ and $10^{\circ}$ standard observer. The reading was performed on a $3-\mathrm{mL}$ milk sample in a $10-\mathrm{mm}$ plastic cuvette. Measured parameters were lightness $\left(\mathrm{L}^{*}\right)$, redness $\left(\mathrm{a}^{*}\right)$, yellowness $\left(\mathrm{b}^{*}\right)$, chroma $\left(\mathrm{C}^{*}\right)$, hue angle $\left(\mathrm{H}^{*}\right)$, and the reflectance spectra between 400 and 700 $\mathrm{nm}$. The reflectance spectrum at wavelengths between 450 and $530 \mathrm{~nm}$ was used to calculate the integral value $\mathrm{I}_{450-530}$ (Priolo et al., 2002).

Laboratory cheese yield was assessed according to the method of Hurtaud et al. (1995). Briefly, $65 \mu \mathrm{L}$ of the same rennet used for cheesemaking was added to $50 \mathrm{~mL}$ of preheated milk in a centrifuge tube and incubated for $1 \mathrm{~h}$ at $35^{\circ} \mathrm{C}$. After a 5 -min pause for syneresis, the coagulum was cut longitudinally using a spatula and centrifuged for $10 \mathrm{~min}$ at $2,700 \times g$ at $35^{\circ} \mathrm{C}$. The weight of curd after removal of whey was recorded, and labora- tory cheese yield was expressed as grams per 100 grams of milk. The individual whey obtained was dried at $100^{\circ} \mathrm{C}$, and the laboratory DM cheese yield (LDMCY) was calculated using the following formula (Hurtaud et al., 1995):

$$
\begin{gathered}
\text { LDMCY }=1-(\text { dry weight of whey/ } \\
\text { dry weight of curd and whey }) .
\end{gathered}
$$

The milk coagulation properties of milk at $35^{\circ} \mathrm{C}$ were analyzed using a milk coagulation meter (Maspres) with a recording interval of $15 \mathrm{~s}$, following the method of Zannoni and Annibaldi (1981). Briefly, the same rennet used for cheesemaking was prediluted with water, and $200 \mu \mathrm{L}$ of the solution was added to $10 \mathrm{~mL}$ of milk to obtain a final concentration of $0.046 \mathrm{IMCU} / \mathrm{mL}$. Determined parameters were clotting time (time needed for the beginning of coagulation), firming time (time needed to reach $20 \mathrm{~mm}$ of amplitude on the chart), and curd firmness (amplitude of the chart, in $\mathrm{mm}$ ) after 30 min and after 2 times clotting time.

\section{Cheese Sampling and Analyses}

After aging, individual cheeses were sampled for analyses and aliquots were vacuum stored at $-20^{\circ} \mathrm{C}$. Color parameters of the fresh-cut surface of each cheese were measured before storing, and the average value of 3 nonoverlapping zones was recorded. The color parameters and device used were the same as those described for milk analyses.

Total $\mathrm{N}$ and DM were measured according to ISO 5534 (ISO, 2004) and ISO 8968-1 (ISO, 2014), respectively. Water-soluble $\mathrm{N}$ and phosphotungstic acid-soluble $\mathrm{N}$ were measured using the method proposed by Ardö (1999). Calcium content in cheese was quantified by back titration with EDTA of ashes (Kindstedt and Kosikowski, 1985). Rheological properties of cheese were assessed by uniaxial compression at constant displacement rate $(1 \mathrm{~mm} / \mathrm{s})$, as reported by Coppa et al. (2011).

Extraction and quantification of fat followed the Röse-Gottlieb method (AOAC, 1990), as modified by Secchiari et al. (2003). Fatty acid profile of cheese was then determined through transesterification using a combined basic and acid methylation, as proposed by Cruz-Hernandez et al. (2004). Briefly, the dry lipid extract was dissolved in hexane to get a final concentration of $30 \mathrm{mg} / \mathrm{mL}$. Then, $0.5 \mathrm{~mL}$ of lipid extract was incubated at $50^{\circ} \mathrm{C}$ for 15 min with $1.5 \mathrm{~mL}$ of sodium methoxide in methanol $(0.5 \mathrm{M})$. After cooling to room temperature, $1 \mathrm{~mL}$ of $5 \%$ methanolic $\mathrm{HCl}$ was added 
and the mixture was incubated at $50^{\circ} \mathrm{C}$ for $30 \mathrm{~min}$. Then, $1 \mathrm{~mL}$ of $6 \%$ aqueous $\mathrm{K}_{2} \mathrm{CO}_{3}$ was added, and a triple centrifugation with $3 \mathrm{~mL}$ of hexane at 1,500 $\times$ $g$ for 10 min at $4^{\circ} \mathrm{C}$ was performed. The supernatants collected after each centrifugation were pooled and evaporated under $\mathrm{N}_{2}$ flow at $37^{\circ} \mathrm{C}$ and then dissolved in $1 \mathrm{~mL}$ of GC-grade hexane. The GC setting for FAME identification was the same as described for feedstuff analysis. Moreover, the separation of $\mathrm{C} 18: 1$ isomers was achieved by isothermal analysis at $165^{\circ} \mathrm{C}$. Individual FA were expressed as grams per 100 grams of total FA.

Odor-active volatile compounds (OAC) were extracted using static solid-phase microextraction as reported by Carpino et al. (2004), with some modifications. A divinylbenzene/carboxen/polydimethylsiloxane coated fiber $(50 / 30 \mu \mathrm{m}$; Supelco) was used to adsorb OAC from the headspace of samples. Samples were prepared by conditioning $10 \mathrm{~g}$ of cheese at $40^{\circ} \mathrm{C}$ for 40 min. An additional 40 min was required for the fiber to establish volatile compound equilibrium between the sample headspace and the fiber solid phase. The fiber was conditioned for $1 \mathrm{~h}$ at $225^{\circ} \mathrm{C}$ before the initial use and for $5 \mathrm{~min}$ between each analysis. For the GCMS analysis and the identification of OAC, a 7890A Series GC system (Agilent Technologies) coupled with an Agilent 5975C Mass Selective Detector (triple axis) was used. An HP-5 capillary column $(30 \mathrm{~m} \times 0.25$-mm i.d. $\times 0.25-\mu \mathrm{m}$ film thickness; Agilent Technologies) was used to separate the volatile components. The chromatographic conditions were as follows: splitless injector at $220^{\circ} \mathrm{C}$; oven program conditions: $35^{\circ} \mathrm{C}$ for $3 \mathrm{~min}, 6^{\circ} \mathrm{C} / \mathrm{min}$ to $200^{\circ} \mathrm{C}$, and $30^{\circ} \mathrm{C} / \mathrm{min}$ to $240^{\circ} \mathrm{C}$ for 3 min. Carrier gas (helium) pressure and flow were set at $93.77 \mathrm{MPa}$ and $1.0 \mathrm{~mL} / \mathrm{min}$, respectively. The mass selective detector operated in scan mode ( 5.15 scans/s) with $70 \mathrm{eV}$ ionization energy. Peaks were identified by comparison of mass spectra with the bibliographic data of the Wiley 175 library (Wiley and Sons Inc.) and with the linear retention indices of authentic standards (Sigma-Aldrich), calculated by running a paraffin series (from C5 to C20) under the same working conditions. The OAC data were expressed as arbitrary units of chromatograph area.

For the GC olfactometry analysis, an HP 6890 Series GC system (Agilent Technologies) GC coupled with an olfactometer was used. Column, injection, and oven setting were the same as reported for GC-MS. A trained human nose (sniffer) was used as a final detector simultaneously with the mass detector (Rapisarda et al., 2014). The eluted compounds were mixed with humidified air, and the sniffer was continuously exposed to this source for $30 \mathrm{~min}$. During the olfactometric analysis, the sniffer described the perceptions and duration of odors. The OAC recognition was performed using the single sniff method (Marin et al., 1988). The sniffer was trained with reference chemicals consisting of a group of 8 compounds used to evaluate olfactory acuity. The sniffer had no specific anosmia for these standards.

\section{Calculations and Statistics}

The index of atherogenicity (IA) and the index of thrombogenicity (IT) were calculated according to Ulbricht and Southgate (1991):

$$
\begin{gathered}
\mathrm{IA}=\frac{\mathrm{C} 12: 0+\mathrm{C} 14: 0+\mathrm{C} 16: 0}{\Sigma \mathrm{MUFA}+\Sigma \mathrm{PUFA}} ; \\
\mathrm{IT}=\frac{\mathrm{C} 14: 0+\mathrm{C} 16: 0+\mathrm{C} 18: 0}{\Sigma \mathrm{MUFA} \times 0.5+\Sigma \mathrm{n}-6 \mathrm{PUFA} \times 0.5} . \\
+\Sigma \mathrm{n}-3 \mathrm{PUFA}+\left(\frac{\Sigma \mathrm{n}-3 \text { PUFA }}{\Sigma \mathrm{n}-6 \mathrm{PUFA}}\right)
\end{gathered}
$$

The hypocholesterolemic to hypercholesterolemic ratio (h:H) was calculated according to Mierliță (2018):

$$
\mathrm{h}: \mathrm{H}=\frac{\mathrm{C} 18: 1 \text { cis }-9+\Sigma \text { PUFA }}{\mathrm{C} 12: 0+\mathrm{C} 14: 0+\mathrm{C} 16: 0} .
$$

Before statistical analysis, SCC data were transformed to $\log _{10}$ per milliliter, and OAC data were transformed to $\ln (\mathrm{x}+1)$ to obtain normalized distribution.

All data from the WS and DS experiments were analyzed separately using an analysis of covariance (ANCOVA) model of SPSS Statistics 21 (IBM), figuring the fixed effect of dietary treatment (CON, TAN). Individual milk and cheese samples were used as statistical unit. Statistical elaboration was adjusted for a covariate composed by (1) the average data of the $2 \mathrm{~d}$ before the beginning of the feeding trials for milk or (2) the data of the day preceding the beginning of the feeding trials for cheese. Differences between means were considered significant at $P \leq 0.05$ and a trend toward significance at $P \leq 0.10$.

\section{RESULTS}

\section{WS Experiment}

Table 2 shows the results for milk composition, color parameters, and cheesemaking aptitude, and Table 3 presents data from measurements during cheesemaking, 
Table 2. Effect of dietary tannin extract supplementation on cow milk yield, chemical composition, color properties, and cheesemaking aptitude in the wet season (WS) and dry season (DS) experiments

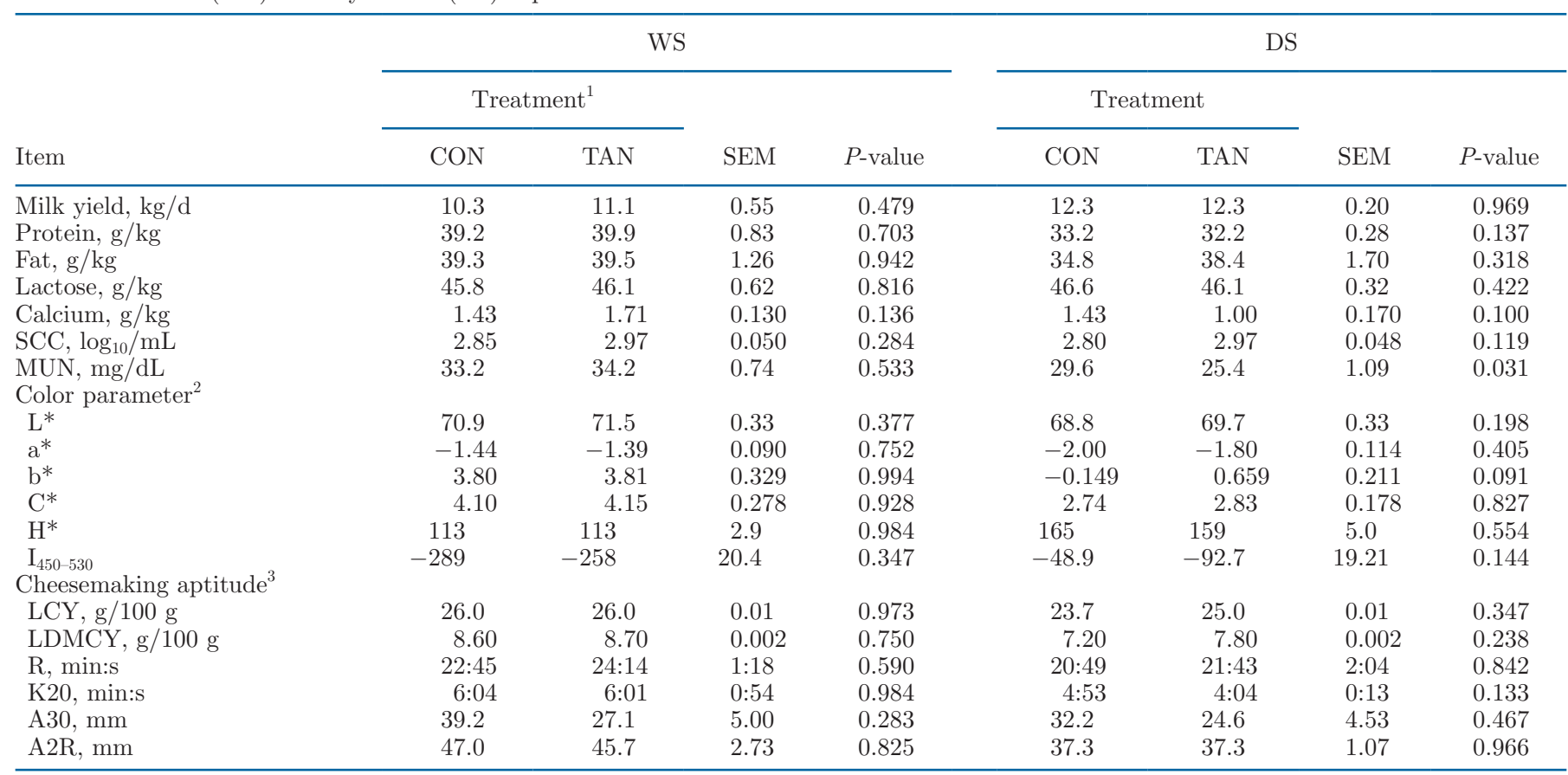

${ }^{1} \mathrm{CON}=$ control group; TAN $=$ group receiving $150 \mathrm{~g}$ of tannin extract/head per day.

${ }^{2} \mathrm{~L}^{*}=$ lightness; $\mathrm{a}^{*}=$ redness; $\mathrm{b}^{*}=$ yellowness; $\mathrm{C}^{*}=$ chroma; $\mathrm{H}^{*}=$ hue angle; $\mathrm{I}_{450-530}=$ integral value of the absorbance spectrum between 450 and $530 \mathrm{~nm}$.

${ }^{3} \mathrm{LCY}=$ laboratory cheese yield; LDMCY = laboratory DM cheese yield; $\mathrm{R}=$ clotting time; K20 = firming time; A30 = curd firmness after 30 min; $\mathrm{A} 2 \mathrm{R}=$ curd firmness after 2 times $\mathrm{R}$.

cheese composition, and cheese physical characteristics. Dietary treatment did not affect $(P>0.05)$ any of these parameters in the WS experiment.

Fatty acids proportion in cheese is reported in Table 4. In the WS experiment, cheese from the TAN group did not differ $(P>0.05)$ from cheese from the CON group, except that it had a higher $(P<0.001)$ proportion of C20:3 n-6. Supplementation with tannin extract did not affect $(P>0.05) \mathrm{BH}$ and healthfulness indices after $23 \mathrm{~d}$ of dietary treatment. A more detailed FA profile is given in Supplemental Table S1 (http://dx.doi .org/10.17632/bb4xjj3fbt.1).

We detected up to 61 different OAC in cheeses from the WS experiment, belonging to the following chemical classes: acids (8), alcohols (13), aldehydes (4), aromatic hydrocarbons (7), esters (9), ketones (8), sulfurs (5), and terpenes (7). However, not all of these OAC were detected in every cheese sample. Therefore, Table 5 shows only the OAC for which statistical analysis could be performed. 2-Nonanone (ketones), ethyl hexanoate (ester), and hexanoic and octanoic acid were the main OAC in WS cheeses. 2-Heptanone was the most abundant compound in $\mathrm{CON}$ cheese, but dietary tannin extract decreased $(P=0.018)$ its concentration.

\section{DS Experiment}

Concerning milk characteristics (Table 2), only MUN differed $(P=0.031)$ between treatments, being lower in the TAN group than in the CON group. Tannin supplementation did not exert any effect $(P>0.05)$ on cheesemaking parameters, cheese composition, and physical characteristics (Table 3) in the DS experiment. The color of cheeses only slightly differed for luminosity, with the TAN group showing a tendency for a higher $(P=0.057) \mathrm{L}^{*}$ value than CON.

Concerning FA profile (Table 4), dietary tannin extract decreased $(P=0.010) \mathrm{C} 18: 1$ trans-10 concentration and tended to increase $(P=0.054) \mathrm{C} 18: 3$ cis-9, cis12, cis-15 concentration. Consequently, we found higher $(P=0.033) \mathrm{C} 18: 1$ trans-11 to $\mathrm{C} 18: 1$ trans-10 ratio and lower $(P=0.031)$ n-6 PUFA to n-3 PUFA ratio (n-6: n-3) in cheeses from the TAN group. A more detailed FA profile is given in Supplemental Table S1.

We detected up to 41 different OAC in cheeses from the DS experiment, belonging to the following chemical classes: acids (5), alcohols (7), aldehydes (2), aromatic hydrocarbons (5), esters (9), ketones (7), sulfurs (2), and terpenes (4). However, not all of these OAC were 
detected in every cheese sample. Therefore, Table 5 shows only the OAC for which statistical analysis could be performed. Ketones were the most abundant compounds in all the cheeses, especially 2-heptanone and 2-nonanone, followed by ethyl butanoate (ester) and hexanoic acid. We found no differences $(P>0.05)$ in the OAC composition between the cheeses of the 2 dietary groups.

\section{DISCUSSION}

\section{Effect on Parameters Related to N Metabolism}

One of the starting hypotheses of this study was that tannins, thanks to their well-known protein-binding and antimicrobial activity (Patra and Saxena, 2011), could affect $\mathrm{N}$ metabolism in vivo and consequently modify some of the cheese parameters related to protein content and composition. However, this occurred only in the DS experiment and was limited to MUN, with no consequences on protein content, proteolysis, or clotting and rheology parameters.

The reduction of MUN in ruminants eating tannins from either extracts or forages is reported in several studies on dairy cows (Broderick et al., 2017; Zhang et al., 2019; Aguerre et al., 2020) and ewes (Buccioni et al., 2015b; Maamouri et al., 2019). This phenomenon is often combined with a lower ureic $\mathrm{N}$ concentration in urine because it is due to an impaired protein ruminal degradation that decreases the concentration of ammonia in the rumen (Patra and Saxena, 2011). As a consequence, ammonia conversion to urea in the liver and subsequent ureic emission from the ruminant are reduced as well as the nitrous oxide emissions from manure, with positive implications for the environment (Naumann et al., 2017). This effect is desirable in the WS, when young green herbage is rich in degradable protein, which may cause a surplus of soluble $\mathrm{N}$ in the

Table 3. Effect of dietary tannin extract supplementation on cow cheese composition, color properties, rheological properties, and cheesemaking measurements in the wet season (WS) and dry season (DS) experiments

\begin{tabular}{|c|c|c|c|c|c|c|c|c|}
\hline Item & \multicolumn{4}{|c|}{ WS } & \multicolumn{4}{|c|}{ DS } \\
\hline \multicolumn{9}{|l|}{ Cheesemaking measurement } \\
\hline Cheese yield, $\mathrm{g} / \mathrm{kg}$ & 112.5 & 112.8 & 3.47 & 0.978 & 83.9 & 83.5 & 2.36 & 0.931 \\
\hline Milk pH & 6.68 & 6.68 & 0.015 & 0.885 & 6.54 & 6.56 & 0.009 & 0.216 \\
\hline Weight after first curd cooking, $\mathrm{g}$ & 1,505 & 1,513 & 70.7 & 0.960 & 1,218 & 1,100 & 29.4 & 0.075 \\
\hline Weight after second curd cooking, $\mathrm{g}$ & 1,031 & 1,083 & 46.5 & 0.591 & 874 & 786 & 29.4 & 0.166 \\
\hline Weight before brining, $g$ & 949 & 952 & 32.7 & 0.968 & 741 & 680 & 19.4 & 0.164 \\
\hline Weight after brining, $\mathrm{g}$ & 950 & 958 & 33.1 & 0.907 & 743 & 683 & 19.4 & 0.167 \\
\hline \multicolumn{9}{|l|}{ Composition $^{2}$} \\
\hline DM, g/100 g & 55.4 & 56.2 & 0.47 & 0.358 & 63.3 & 62.4 & 0.95 & 0.643 \\
\hline Fat, g/100 g & 17.8 & 18.4 & 0.80 & 0.688 & 19.7 & 20.5 & 0.92 & 0.691 \\
\hline \multirow{2}{*}{\multicolumn{9}{|c|}{ Color parameter ${ }^{3}$}} \\
\hline & & & & & & & & \\
\hline $\mathrm{L}^{*}$ & 83.2 & 83.8 & 0.89 & 0.722 & 77.0 & 79.9 & 0.94 & 0.057 \\
\hline$a^{*}$ & 3.76 & 3.70 & 0.111 & 0.783 & 1.70 & 1.93 & 0.106 & 0.154 \\
\hline $\mathrm{b}^{*}$ & 19.9 & 20.4 & 0.60 & 0.679 & 9.57 & 10.21 & 0.420 & 0.306 \\
\hline $\mathrm{C}^{*}$ & 20.2 & 20.8 & 0.61 & 0.698 & 9.72 & 10.40 & 0.425 & 0.288 \\
\hline $\mathrm{H}^{*}$ & 79.4 & 79.6 & 0.11 & 0.406 & 79.6 & 79.7 & 0.28 & 0.757 \\
\hline $\mathrm{I}_{450-530}$ & $-1,152$ & $-1,211$ & 37.7 & 0.493 & -438 & -509 & 32.4 & 0.156 \\
\hline \multicolumn{9}{|l|}{ Rheology, $\mathrm{N} / \mathrm{cm}^{2}$} \\
\hline Strength to $20 \%$ deformation & 2.18 & 2.60 & 0.236 & 0.234 & 6.53 & 5.58 & 1.003 & 0.523 \\
\hline Strength to $40 \%$ deformation & 6.02 & 6.89 & 0.614 & 0.339 & 15.6 & 12.8 & 1.88 & 0.324 \\
\hline Strength to $60 \%$ deformation & 8.29 & 9.47 & 0.670 & 0.243 & 20.8 & 16.6 & 2.29 & 0.231 \\
\hline Young modulus (undeformability) & 25.0 & 27.7 & 2.00 & 0.358 & 63.6 & 47.9 & 11.90 & 0.372 \\
\hline
\end{tabular}


rumen (Kingston-Smith and Theodorou, 2000). In the WS experiment in the present study, the lack of reduction in MUN in the TAN group may be due to the high level of $\mathrm{CP}$ intake from green pasture, which hid the effect of tannin extract supplementation at the dosage used here. A higher proportion of tannins in DMI likely could have resulted in a significant effect in the WS experiment, as the effect of tannins on rumen fermentation is often dose dependent (Toral et al., 2018). However, a high intake of tannins could have detrimental consequences on animal performance (Aguerre et al., 2016) and could be economically impractical on a commercial farm.

On the other hand, the literature lacks studies assessing the effect of dietary tannins on the physical properties of cow cheese or the cheesemaking aptitude of cow milk. Kälber et al. (2013) found that milk of cows eating $6.1 \mathrm{~g} / \mathrm{d}$ of condensed tannins from buckwheat (Fagopyrum esculentum Moench) forage had a shorter clotting time compared with milk of cows eating 2.2 $\mathrm{g} / \mathrm{d}$ of condensed tannins from chicory (Cichorium intybus L.) or ryegrass (Lolium multiflorum Lam.) forage. However, the authors did not observe any differences in milk composition that could explain that positive result. In another study, a trained panel noted moderate differences in hardness and adhesiveness of Gruyère cheese from Holstein cows eating $691 \mathrm{~g} /$ head per day of condensed tannins from sainfoin (Onobrychis viciifolia Scop.) pellets, but no difference in protein or casein content was observed in the milk used for cheesemaking (Girard et al., 2016). Additional information can be collected from experiments on small ruminants,

Table 4. Effect of dietary tannin extract supplementation on cow cheese fatty acid (FA) profile (g/100 g of total FA) in the wet season (WS) and dry season (DS) experiments

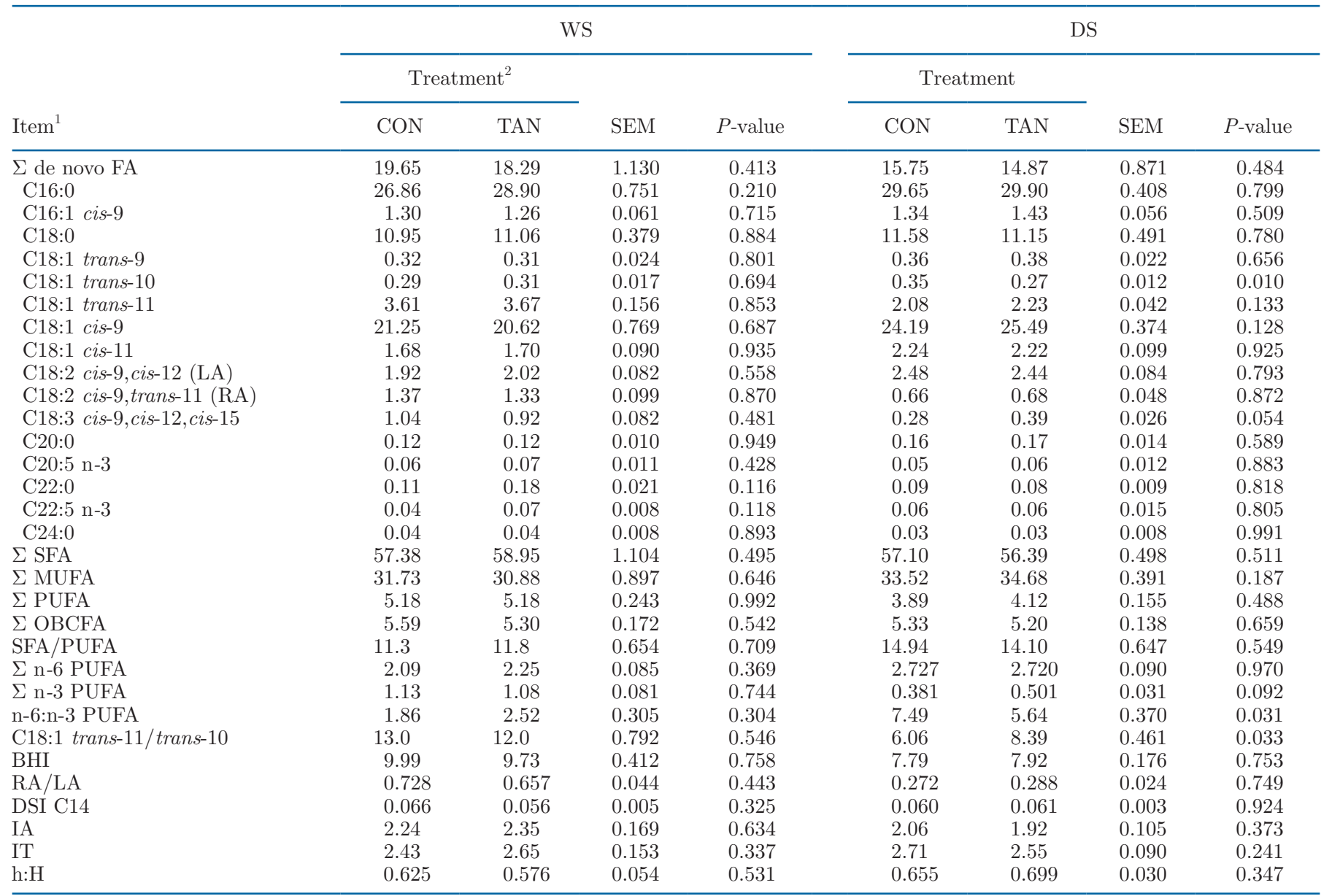

${ }^{1}$ de novo FA $=$ C4:0 + C6:0 + C8:0 + C10:0 + C12:0 + C14:0; OBCFA = odd- and branched-chain fatty acids; BHI = biohydrogenation intermediates; DSI C14 = desaturation index, calculated as C14:1 cis-9/(C14:0 + C14:1 cis-9); IA = index of atherogenicity (Ulbricht and Southgate, 1991); IT = index of thrombogenicity (Ulbricht and Southgate, 1991); h:H = hypocholesterolemic:hypercolesterolemic ratio (Mierliță, 2018); LA $=$ linoleic acid; $\mathrm{RA}=$ rumenic acid.

${ }^{2} \mathrm{CON}=$ control group; TAN $=$ group receiving $150 \mathrm{~g}$ of tannin extract/head per day. 
although caution is needed when knowledge is extrapolated from different ruminant species, as it is a relevant source of variation. Some articles reported no effect of dietary quebracho or chestnut tannin extracts on ewe milk clotting parameters (Buccioni et al., 2015a,b) or even longer clotting and firming time (Buccioni et al., 2017), probably related to the interference with caseins or rennin of some bioactive monomers derived from tannin biodegradation. Bonanno et al. (2016) observed a positive effect on ewe milk and cheese protein content when animals grazed on sulla (Sulla coronaria Medik.) compared with ryegrass. These results were attributed to the presence of condensed tannins in sulla; however, animals grazing ryegrass had a significantly lower CP daily intake $(-53 \%)$. In summary, a recent meta-analysis by Herremans et al. (2020) concluded that dietary tannins do not have any effect on $\mathrm{N}$ use efficiency in dairy cattle, except for the reduction of urea emissions, which is beneficial for the environment.

\section{Effect on FA Profile}

The significant reduction of $\mathrm{n}-6: \mathrm{n}-3$ in 25 -d-old cheeses from cows ingesting tannin extract in the DS experiment is most likely related to the effect of tannins on rumen BH. Indeed, the milk FA synthesized de novo in animal tissues are mainly SFA, or they result from the activity of desaturase and elongase enzymes (Palmquist, 2006). Milk C18:2 cis-9,cis-12 and C18:3 cis-9,cis-12,cis-15, the most relevant $\mathrm{n}-6$ and n-3 PUFA, respectively, are mainly of dietary origin, and their concentration can be modified by modulating BH (Chilliard et al., 2007). A lower dietary n-6:n -3 could reduce cardiovascular disease risk in human, especially if achieved as a result of an increase in C18:3 cis-9,cis-12,cis-15 concentration (Harris, 2006), as occurred in our study. Likewise, Girard et al. (2016) reported an increase of $17 \%$ of $\mathrm{C} 18: 3$ cis- 9 , cis- 12 , cis- 15 proportion in cheese from cows fed sainfoin pellets $(691$

Table 5. Effect of dietary tannin extract supplementation on proportion of cow cheese odor-active volatile compounds ${ }^{1}$ (OAC) in wet season (WS) and dry season (DS) experiments (expressed as arbitrary units of chromatograph area)

\begin{tabular}{|c|c|c|c|c|c|c|c|c|c|c|}
\hline \multirow[b]{3}{*}{ Item } & \multirow[b]{3}{*}{$\begin{array}{l}\text { Odor } \\
\text { perception }\end{array}$} & \multirow[b]{3}{*}{$\mathrm{LRI}^{2}$} & \multicolumn{4}{|c|}{ WS } & \multicolumn{4}{|c|}{ DS } \\
\hline & & & \multicolumn{2}{|c|}{ Treatment $^{3}$} & \multirow[b]{2}{*}{ SEM } & \multirow[b]{2}{*}{$P$-value } & \multicolumn{2}{|c|}{ Treatment } & \multirow[b]{2}{*}{ SEM } & \multirow[b]{2}{*}{$P$-value } \\
\hline & & & $\mathrm{CON}$ & TAN & & & $\mathrm{CON}$ & TAN & & \\
\hline Acids, total & & & 17.4 & 16.9 & 0.27 & 0.345 & 16.3 & 16.3 & 0.80 & 0.895 \\
\hline Butanoic acid & Cheese & 820 & 15.4 & 13.9 & 0.77 & 0.342 & 12.5 & 10.6 & 1.12 & 0.413 \\
\hline 3-Methylbutanoic acid & Rancid, cheese & 877 & 14.5 & 14.5 & 0.92 & 0.934 & - & - & - & - \\
\hline Decanoic acid & Rancid & 1,373 & 14.3 & 11.5 & 1.04 & 0.198 & 11.5 & 10.9 & 1.28 & 0.803 \\
\hline Alcohols, total & & & 13.1 & 13.9 & 0.87 & 0.665 & 13.4 & 13.6 & 0.89 & 0.875 \\
\hline 3-Methylacetatebutan-1-ol & Banana & 876 & - & - & - & - & 10.8 & 11.9 & 1.06 & 0.630 \\
\hline 2-Ethylhexan-1-ol & Rose, green & 1,032 & 11.0 & 11.3 & 1.11 & 0.889 & 11.3 & 12.8 & 0.85 & 0.401 \\
\hline Aldehydes, total & & & 10.5 & 10.5 & 1.02 & 0.981 & 8.9 & 10.3 & 0.99 & 0.498 \\
\hline Nonanal & Fresh, green & 1,104 & 10.5 & 10.5 & 1.02 & 0.997 & 8.8 & 10.3 & 0.99 & 0.464 \\
\hline Aromatic hydrocarbons, total & & & 15.9 & 16.3 & 0.23 & 0.526 & 14.3 & 14.3 & 0.63 & 0.924 \\
\hline Ethyl butanoate & Apple & 804 & 12.7 & 13.4 & 1.06 & 0.781 & 15.0 & 15.8 & 1.08 & 0.228 \\
\hline Ethyl hexanoate & Orange & 1,000 & 15.9 & 16.4 & 0.71 & 0.295 & 14.3 & 14.7 & 1.10 & 0.884 \\
\hline Ethyl octanoate & Wine & 1,198 & 14.9 & 14.8 & 0.60 & 0.969 & 11.5 & 13.6 & 1.06 & 0.348 \\
\hline Ethyl decanoate & Grape & 1,398 & 12.4 & 10.3 & 0.77 & 0.200 & 10.6 & 12.1 & 0.84 & 0.421 \\
\hline Ketones, total & & & 18.2 & 16.7 & 0.35 & 0.078 & 18.0 & 18.0 & 0.43 & 0.990 \\
\hline 2-Heptanone & Soap, fruit & 895 & 18.2 & 14.0 & 0.66 & 0.018 & 18.2 & 17.8 & 0.47 & 0.534 \\
\hline 2-Octanone & Solvent & 999 & 12.6 & 12.4 & 0.90 & 0.924 & 14.4 & 13.8 & 0.95 & 0.246 \\
\hline 2-Nonanone & Hot milk & 1,093 & 17.0 & 15.9 & 0.43 & 0.267 & 17.1 & 17.2 & 0.41 & 0.836 \\
\hline 2-Undecanone & Orange & 1,296 & - & - & - & - & 13.1 & 13.0 & 0.88 & 0.944 \\
\hline Terpenes, total & & & 9.9 & 11.4 & 0.96 & 0.441 & - & - & - & - \\
\hline$\alpha$-Pinene & Fresh & 939 & 9.0 & 9.7 & 0.95 & 0.726 & - & - & - & - \\
\hline
\end{tabular}

${ }^{1}$ All OAC reported in this table were identified using both an Agilent 5975C Mass Selective Detector and the bibliographic data of the Wiley 175 library (Wiley and Sons Inc.).

${ }^{2} \mathrm{LRI}=$ linear retention index.

${ }^{3} \mathrm{CON}=$ control group; TAN $=$ group receiving $150 \mathrm{~g}$ of tannin extract $/$ head per day. 
$\mathrm{g}$ of condensed tannins/head per day) compared with the control group (alfalfa, Medicago sativa L.). Also, dietary tannins were suggested to be responsible for the increase in C18:3 cis-9,cis-12,cis-15 in 60-d-old cheese from ewes fed fresh sulla forage, although tannin content in diets was not investigated (Addis et al., 2005). Unfortunately, the tendentially higher n-3 PUFA concentration found in TAN in the present study cheese was not enough to improve the healthfulness indices (i.e., IA, IT, and h:H).

When the effects of dietary tannins are investigated in vivo, a shift in milk C18:3 cis-9,cis- 12 , cis-15 concentration is generally combined with changes in the concentration of other $\mathrm{FA}$ involved in $\mathrm{BH}$, such as C18:2 cis-9,cis-12, C18:0, C18:1 trans-11, and C18:2 cis-9,trans-11 (Cabiddu et al., 2009; Buccioni et al., 2015a,b). However, Frutos et al. (2020) summarized in a recent review that although dietary tannins are commonly found to increase C18:3 cis-9,cis-12,cis-15 concentration in milk, regardless of the tannin source, the effects on $\mathrm{C} 18: 2$ cis-9,cis-12 and C18:0 are less consistent. In the DS experiment, dietary tannin extract exerted no effect on these protagonists of $\mathrm{BH}$, but we observed a significant decrease in C18:1 trans-10 concentration. As the microbial conversion of $\mathrm{C} 18: 3$ cis-9,cis-12,cis-15 to C18:1 trans-10 may occur in the rumen (Bessa et al., 2015), dietary tannin extract may have affected this particular pathway in the DS experiment. An increase in C18:3 cis-9, cis-12, cis-15 concentration and a reduction of $\mathrm{C} 18: 1$ trans-10 concentration in milk due to tannin ingestion (26.5 g of condensed tannins $/ \mathrm{kg}$ of DMI) was also reported by Cabiddu et al. (2009) in ewes eating fresh sulla, but this effect was also combined with changes in other FA concentrations. Other studies on dietary tannin supplementation to dairy cows reported no effect on C18:1 trans-10 concentration in cow milk (Dschaak et al., 2011; Henke et al., 2017), but it should be emphasized that this FA is often not reported in scientific articles or its concentration is summed with that of C18:1 trans-11, as they easily coelute in GC.

Conversely, it seems that dietary tannin supplementation did not affect ruminal $\mathrm{BH}$ in the WS experiment according to cheese FA profile. In a study comparing the effect of 2 different tannin extracts (quebracho vs. chestnut and quebracho) on FA profile of in vitro rumen fermentation with different forage substrates, hay was found to be more susceptible than green herbage to tannin bioactivity (Menci et al., 2021). Because diet is likely the major factor affecting rumen microbiota composition (Ellison et al., 2017), the low protein content or the high structural carbohydrate content of dry forages or both may select a particular microbiota that is more sensitive to the effects of tannin. The results of the present study confirm this phenomenon in vivo with cows, considering that ruminal microorganisms are among the main factors responsible for FA profile of milk and dairy (Palmquist, 2006). Indeed, the diet in the DS experiment was poorer in $\mathrm{CP}$ and richer in $\mathrm{ADL}$ compared with the WS experiment, as the chemical composition of the stubble grazed by cows was comparable with that of hay. Further studies on rumen microbiota involving different tannin sources and types are needed to confirm our hypothesis.

\section{Effect on OAC}

Dietary tannin extract supplementation did not exert any effect on the aroma of DS cheeses, but it did affect ketone concentration in the WS experiment, particularly 2-heptanone concentration. Methyl ketones originate from the $\beta$-oxidation of lipolyzed FA by microorganisms (McSweeney and Sousa, 2000); therefore, they are known to characterize the aroma of blue and surfacemold ripened cheeses. Their presence is also reported in different kinds of cheese (Curioni and Bosset, 2002). Interestingly, herd management affected the presence of ketones in cheese. Valdivielso et al. (2016) observed a significant increase of 2-heptanone and 2-nonanone in cheese from ewes grazing mountain pastures, and Carpino et al. (2004) found acetoin and 2-nonanone only in cheese from grazing cows even though none of these compounds were detected in pasture. At the moment, it is not clear how dietary tannins affected ketone concentration or whether they acted against lipolysis or $\beta$-oxidation enzymes. Further research should investigate this aspect, as the literature is devoid of studies on the effect of dietary tannins on aromatic compounds in milk and cheese. In summary, the slight differences in OAC concentrations of cow cheese induced by dietary tannin extract at the dose used in this study would likely not affect the consumer sensory experience.

\section{CONCLUSIONS}

The inclusion of tannin extract in the diet of dairy cows at a rate of $1 \%$ of estimated DMI for $23 \mathrm{~d}$ slightly affected the composition and OAC of cow cheese. The results of the present study indicated that this rate of tannin supplementation has no detrimental effects on cheese yield or other cheesemaking parameters regardless of the variation in cow diet induced by forage availability according to the season of the Mediterranean climate. The bioactivity of dietary tannins appears to 
be more efficient during the DS, when the diet is low in $\mathrm{CP}$ and rich in ADF and ADL. Further studies are needed to investigate the effects of longer supplementations or different doses and tannin sources.

\section{ACKNOWLEDGMENTS}

The authors acknowledge the financial support provided by transnational funding bodies that are partners of the H2020 ERA-net project "CORE Organic Cofund" and the cofund from the European Commission, under the project ProYoungStock "Promoting young stock and cow health and welfare by natural feeding systems." Moreover, the authors acknowledge the University of Catania (Catania, Italy) for funding part of the research conducted (project "QUALIGEN"; Linea 2 - Piano di Incentivi per la Ricerca di Ateneo 2020/2022; principal investigator Giuseppe Luciano). R. Menci was granted fellowship by Programma Operativo Nazionale Ricerca e Innovazione 2014-2020, "Dottorati Innovativi con caratterizzazione Industriale" Borsa di studio DOT1308937-1 - CUP: E67I18001070006, PhD course in Agricultural, Food and Environmental Science of the University of Catania. The authors also acknowledge Silvateam s.p.a. (San Michele Mondovì, Cuneo, Italy) for providing the tannin extracts used in this experiment. The authors declare no conflicts of interest.

\section{REFERENCES}

Addis, M., A. Cabiddu, G. Pinna, M. Decandia, G. Piredda, A. Pirisi, and G. Molle. 2005. Milk and cheese fatty acid composition in sheep fed Mediterranean forages with reference to conjugated linoleic acid cis-9,trans-11. J. Dairy Sci. 88:3443-3454. https://doi .org/10.3168/jds.S0022-0302(05)73028-9.

Aguerre, M. J., M. C. Capozzolo, P. Lencioni, C. Cabral, and M. A. Wattiaux. 2016. Effect of quebracho-chestnut tannin extracts at 2 dietary crude protein levels on performance, rumen fermentation, and nitrogen partitioning in dairy cows. J. Dairy Sci. 99:44764486. https://doi.org/10.3168/jds.2015-10745.

Aguerre, M. J., B. Duval, J. M. Powell, P. A. Vadas, and M. A. Wattiaux. 2020. Effects of feeding a quebracho-chestnut tannin extract on lactating cow performance and nitrogen utilization efficiency. J. Dairy Sci. 103:2264-2271. https://doi.org/10.3168/jds.2019-17442.

AOAC. 1990. Official Method of Analysis. 15th ed. AOAC.

AOAC International. 1995. Official Method of Analysis. 16th ed. AOAC International.

Ardö, Y. 1999. Evaluating proteolysis by analysing the $\mathrm{N}$ content of cheese fractions. Bull. Int. Dairy Fed. 337:4-7.

Bessa, R. J. B., S. P. Alves, and J. Santos-Silva. 2015. Constraints and potentials for the nutritional modulation of the fatty acid composition of ruminant meat. Eur. J. Lipid Sci. Technol. 117:1325-1344. https://doi.org/10.1002/ejlt.201400468.

Bonanno, A., A. Di Grigoli, F. Mazza, C. De Pasquale, C. Giosuè, F. Vitale, and M. Alabiso. 2016. Effects of ewes grazing sulla or ryegrass pasture for different daily durations on forage intake, milk production and fatty acid composition of cheese. Animal 10:20742082. https://doi.org/10.1017/S1751731116001130.

Broderick, G. A., J. H. Grabber, R. E. Muck, and U. C. Hymes-Fecht, 2017. Replacing alfalfa silage with tannin-containing birdsfoot tre- foil silage in total mixed rations for lactating dairy cows. J. Dairy Sci. 100:3548-3562. https://doi.org/10.3168/jds.2016-12073.

Buccioni, A., M. Pauselli, S. Minieri, V. Roscini, F. Mannelli, S. Rapaccini, P. Lupi, G. Conte, A. Serra, A. Cappucci, L. Brufani, F. Ciucci, and M. Mele. 2017. Chestnut or quebracho tannins in the diet of grazing ewes supplemented with soybean oil: Effects on animal performances, blood parameters and fatty acid composition of plasma and milk lipids. Small Rumin. Res. 153:23-30. https:// doi.org/10.1016/j.smallrumres.2017.05.006.

Buccioni, A., M. Pauselli, C. Viti, S. Minieri, G. Pallara, V. Roscini, S. Rapaccini, M. T. Marinucci, P. Lupi, G. Conte, and M. Mele. 2015a. Milk fatty acid composition, rumen microbial population, and animal performances in response to diets rich in linoleic acid supplemented with chestnut or quebracho tannins in dairy ewes. J. Dairy Sci. 98:1145-1156. https://doi.org/10.3168/jds.2014-8651.

Buccioni, A., A. Serra, S. Minieri, F. Mannelli, A. Cappucci, D. Benvenuti, S. Rapaccini, G. Conte, and M. Mele. 2015b. Milk production, composition, and milk fatty acid profile from grazing sheep fed diets supplemented with chestnut tannin extract and extruded linseed. Small Rumin. Res. 130:200-207. https://doi.org/10.1016/ j.smallrumres.2015.07.021.

Cabiddu, A., G. Molle, M. Decandia, S. Spada, M. Fiori, G. Piredda, and M. Addis. 2009. Responses to condensed tannins of flowering sulla (Hedysarum coronarium L.) grazed by dairy sheep. Part 2: Effects on milk fatty acid profile. Livest. Sci. 123:230-240. https:/ /doi.org/10.1016/j.livsci.2008.11.019.

Carpino, S., S. Mallia, S. La Terra, C. Melilli, G. Licitra, T. E. Acree, D. M. Barbano, and P. J. Van Soest. 2004. Composition and aroma compounds of Ragusano cheese: Native pasture and total mixed rations. J. Dairy Sci. 87:816-830. https://doi.org/10.3168/ jds.S0022-0302(04)73226-9.

Chilliard, Y., F. Glasser, A. Ferlay, L. Bernard, J. Rouel, and M. Doreau. 2007. Diet, rumen biohydrogenation and nutritional quality of cow and goat milk fat. Eur. J. Lipid Sci. Technol. 109:828855. https://doi.org/10.1002/ejlt.200700080.

Coppa, M., C. Chassaing, C. Sibra, A. Cornu, J. Verbič, J. Golecký, E. Engel, J. Ratel, A. Boudon, A. Ferlay, and B. Martin. 2019. Forage system is the key driver of mountain milk specificity. J. Dairy Sci 102:10483-10499. https://doi.org/10.3168/jds.2019-16726.

Coppa, M., A. Ferlay, F. Monsallier, I. Verdier-Metz, P. Pradel, R. Didienne, A. Farruggia, M. C. Montel, and B. Martin. 2011. Milk fatty acid composition and cheese texture and appearance from cows fed hay or different grazing systems on upland pastures. J. Dairy Sci. 94:1132-1145. https://doi.org/10.3168/jds.2010-3510.

Cruz-Hernandez, C., Z. Deng, J. Zhou, A. R. Hill, M. P. Yurawecz, P. Delmonte, M. M. Mossoba, M. E. R. Dugan, and J. K. G. Kramer. 2004. Methods for analysis of conjugated linoleic acids and trans-18:1 isomers in dairy fats by using a combination of gas chromatography, silver-ion thin-layer chromatography/gas chromatography, and silver-ion liquid chromatography. J. AOAC Int. 87:545-562. https://doi.org/10.1093/jaoac/87.2.545.

Curioni, P. M. G., and J. O. Bosset. 2002. Key odorants in various cheese types as determined by gas chromatography-olfactometry. Int. Dairy J. 12:959-984. https://doi.org/10.1016/S0958 -6946(02)00124-3.

Daget, P., and J. Poissonet. 1971. Une méthode d'analyse phytologique des prairies: Critères d'application. Ann. Agron. 22:5-41.

Dschaak, C. M., C. M. Williams, M. S. Holt, J. S. Eun, A. J. Young, and B. R. Min. 2011. Effects of supplementing condensed tannin extract on intake, digestion, ruminal fermentation, and milk production of lactating dairy cows. J. Dairy Sci. 94:2508-2519. https: //doi.org/10.3168/jds.2010-3818.

Ellison, M. J., G. C. Conant, W. R. Lamberson, R. R. Cockrum, K. J. Austin, D. C. Rule, and K. M. Cammack. 2017. Diet and feed efficiency status affect rumen microbial profiles of sheep. Small Rumin. Res. 156:12-19. https://doi.org/10.1016/j.smallrumres 2017.08.009.

Frutos, P., G. Hervás, A. Natalello, G. Luciano, M. Fondevila, A. Priolo, and P. G. Toral. 2020. Ability of tannins to modulate ruminal lipid metabolism and milk and meat fatty acid profiles. 
Anim. Feed Sci. Technol. 269:114623. https://doi.org/10.1016/j .anifeedsci.2020.114623.

Girard, M., F. Dohme-Meier, D. Wechsler, D. Goy, M. Kreuzer, and G. Bee. 2016. Ability of 3 tanniferous forage legumes to modify quality of milk and Gruyère-type cheese. J. Dairy Sci. 99:205-220. https://doi.org/10.3168/jds.2015-9952.

Guinee, T. P. 2003. Role of protein in cheese and cheese products. Pages 1083-1174 in Advanced Dairy Chemistry. Vol. 1: Proteins. P. F. Fox and P. L. H. McSweeney, ed. Springer. https://doi.org/ 10.1007/978-1-4419-8602-3_31.

Harris, W. S. 2006. The omega-6/omega-3 ratio and cardiovascular disease risk: Uses and abuses. Curr. Atheroscler. Rep. 8:453-459. https://doi.org/10.1007/s11883-006-0019-7.

Henke, A., E. Westreicher-Kristen, J. Molkentin, U. Dickhoefer, K. Knappstein, M. Hasler, and A. Susenbeth. 2017. Effect of dietary quebracho tannin extract on milk fatty acid composition in cows. J. Dairy Sci. 100:6229-6238. https://doi.org/10.3168/jds.2016 -12149 .

Herremans, S., F. Vanwindekens, V. Decruyenaere, Y. Beckers, and E. Froidmont. 2020. Effect of dietary tannins on milk yield and composition, nitrogen partitioning and nitrogen use efficiency of lactating dairy cows: A meta-analysis. J. Anim. Physiol. Anim. Nutr. (Berl.) 104:1209-1218. https://doi.org/10.1111/jpn.13341.

Hurtaud, C., H. Rulquin, M. Delaite, and R. Vérité. 1995. Prediction of cheese yielding efficiency of individual milk of dairy cows. Correlation with coagulation parameters and laboratory curd yield. Ann. Zootech. 44:385-398. https://doi.org/10.1051/animres:19950405.

INRA (Institut National de la Recherche Agronomique). 2018. Alimentation des Ruminants. Editions Quae.

ISO (International Organization for Standardization). 2004. Cheese and processed cheese-Determination of the total solid content. Method no. 5534. ISO.

ISO. (International Organization for Standardization). 2006. MilkEnumeration of somatic cells - Part 2: Guidance on the operation of fluoro-opto-electronic counters. Method no. 13366-2. ISO.

ISO. (International Organization for Standardization). 2013. Milk and liquid milk products - Guidelines for the application of mid-infrared spectrometry. Method no. 9622. ISO.

ISO (International Organization for Standardization). 2014. Milk and milk products - Determination of nitrogen content-Part 1: Kjeldahl principle and crude protein calculation. Method no. 8968-1. ISO.

Kälber, T., M. Kreuzer, and F. Leiber. 2013. Effect of feeding buckwheat and chicory silages on fatty acid profile and cheese-making properties of milk from dairy cows. J. Dairy Res. 80:81-88. https: //doi.org/10.1017/S0022029912000647.

Kindstedt, P. S., and F. V. Kosikowski. 1985. Improved complexometric determination of calcium in cheese. J. Dairy Sci. 68:806-809. https://doi.org/10.3168/jds.S0022-0302(85)80896-1.

Kingston-Smith, A. H., and M. K. Theodorou. 2000. Tansley review no. 118: Post-ingestion metabolism of fresh forage. New Phytol. 148:37-55. https://doi.org/10.1046/j.1469-8137.2000.00733.x.

Licitra, G., R. W. Blake, P. A. Oltenacu, S. Barresi, S. Scuderi, and P. J. Van Soest. 1998. Assessment of the dairy production needs of cattle owners in southeastern Sicily. J. Dairy Sci. 81:2510-2517. https://doi.org/10.3168/jds.S0022-0302(98)70143-2.

Licitra, G., T. M. Hernandez, and P. J. Van Soest. 1996. Standardization of procedures for nitrogen fractionation of ruminant feeds. Anim. Feed Sci. Technol. 57:347-358. https://doi.org/10.1016/ 0377-8401(95)00837-3.

Luciano, G., A. Natalello, S. Mattioli, M. Pauselli, B. Sebastiani, V. Niderkorn, G. Copani, H. Benhissi, A. Amanpour, and B. Valenti. 2019. Feeding lambs with silage mixtures of grass, sainfoin and red clover improves meat oxidative stability under high oxidative challenge. Meat Sci. 156:59-67. https://doi.org/10.1016/j.meatsci 2019.05.020

Maamouri, O., M. Mahouachi, K. Kraiem, and N. Atti. 2019. Milk production, composition and milk fatty acid profile from grazing ewes fed diets supplemented with Acacia cyanophylla leaves as tannins source and whole or extruded linseed. Livest. Sci. 227:120127. https://doi.org/10.1016/j.livsci.2019.06.024.
Makkar, H. P. S., M. Blümmel, N. K. Borowy, and K. Becker. 1993. Gravimetric determination of tannins and their correlations with chemical and protein precipitation methods. J. Sci. Food Agric. 61:161-165. https://doi.org/10.1002/jsfa.2740610205.

Marin, A. B., T. E. Acree, and J. Barnard. 1988. Variation in odor detection thresholds determined by charm analysis. Chem. Senses 13:435-444. https://doi.org/10.1093/chemse/13.3.435.

McSweeney, P. L. H., and M. J. Sousa. 2000. Biochemical pathways for the production of flavour compounds in cheeses during ripening: A review. Lait 80:293-324. https://doi.org/10.1051/lait:2000127.

Menci, R., M. Coppa, A. Torrent, A. Natalello, B. Valenti, G. Luciano, A. Priolo, and V. Niderkorn. 2021. Effects of two tannin extracts at different doses in interaction with a green or dry forage substrate on in vitro rumen fermentation and biohydrogenation. Anim. Feed Sci. Technol. https://doi.org/10.1016/j.anifeedsci 2021.114977. In press

Mierliță, D. 2018. Effects of diets containing hemp seeds or hemp cake on fatty acid composition and oxidative stability of sheep milk. S. Afr. J. Anim. Sci. 48:504-515. https://doi.org/10.4314/sajas.v48i3 11.

Min, B. R., G. T. Attwood, K. Reilly, W. Sun, J. S. Peters, T. N. Barry, and W. C. McNabb. 2002. Lotus corniculatus condensed tannins decrease in vivo populations of proteolytic bacteria and affect nitrogen metabolism in the rumen of sheep. Can. J. Microbiol. 48:911-921. https://doi.org/10.1139/w02-087.

Natalello, A., G. Luciano, L. Morbidini, B. Valenti, M. Pauselli, P. Frutos, L. Biondi, P. J. Rufino-Moya, M. Lanza, and A. Priolo. 2019. Effect of feeding pomegranate byproduct on fatty acid composition of ruminal digesta, liver, and muscle in lambs. J. Agric. Food Chem. 67:4472-4482. https://doi.org/10.1021/acs.jafc 9b00307.

Naumann, H. D., L. O. Tedeschi, W. E. Zeller, and N. F. Huntley. 2017. The role of condensed tannins in ruminant animal production: Advances, limitations and future directions. Rev. Bras. Zootec. 46:929-949. https://doi.org/10.1590/s1806-92902017001200009.

Palmquist, D. L. 2006. Milk fat: Origin of fatty acids and influence of nutritional factors thereon. Pages 43-92 in Advanced Dairy Chemistry. Vol. 2: Lipids. P. F. Fox and P. L. H. McSweeney, ed. Springer.

Patra, A. K., and J. Saxena. 2011. Exploitation of dietary tannins to improve rumen metabolism and ruminant nutrition. J. Sci. Food Agric. 91:24-37. https://doi.org/10.1002/jsfa.4152.

Prache, S., B. Martin, and M. Coppa. 2020. Review: Authentication of grass-fed meat and dairy products from cattle and sheep. Animal 14:854-863. https://doi.org/10.1017/S1751731119002568.

Priolo, A., S. Prache, D. Micol, and J. Agabriel. 2002. Reflectance spectrum of adipose tissue to trace grass feeding in sheep: Influence of measurement site and shrinkage time after slaughter. J. Anim. Sci. 80:886-891. https://doi.org/10.2527/2002.804886x.

Ramírez-Rivera, E. J., J. Rodríguez-Miranda, I. R. Huerta-Mora, A. Cárdenas-Cágal, and J. M. Juárez-Barrientos. 2019. Tropical milk production systems and milk quality: A review. Trop. Anim. Health Prod. 51:1295-1305. https://doi.org/10.1007/s11250-019 $-01922-1$.

Rapisarda, T., C. Pasta, S. Carpino, M. Caccamo, M. Ottaviano, and G. Licitra. 2014. Volatile profile differences between spontaneous and cultivated Hyblean pasture. Anim. Feed Sci. Technol. 191:3946. https://doi.org/10.1016/j.anifeedsci.2014.02.003

Secchiari, P., M. Antongiovanni, M. Mele, A. Serra, A. Buccioni, G. Ferruzzi, F. Paoletti, and F. Petacchi. 2003. Effect of kind of dietary fat on the quality of milk fat from Italian Friesian cows. Livest. Prod. Sci. 83:43-52. https://doi.org/10.1016/S0301 $-6226(03) 00043-5$.

Toral, P. G., F. J. Monahan, G. Hervás, P. Frutos, and A. P. Moloney. 2018. Modulating ruminal lipid metabolism to improve the fatty acid composition of meat and milk. Challenges and opportunities. Animal 12(Suppl. 2):S272-S281. https://doi.org/10.1017/ S1751731118001994.

Ulbricht, T. L. V., and D. A. T. Southgate. 1991. Coronary heart disease: Seven dietary factors. Lancet 338:985-992. https://doi.org/ 10.1016/0140-6736(91)91846-m. 
Valdivielso, I., M. A. Bustamante, A. Aldezabal, G. Amores, M. Virto, J. C. Ruiz de Gordoa, M. de Renobales, and L. J. R. Barron. 2016. Case study of a commercial sheep flock under extensive mountain grazing: Pasture derived lipid compounds in milk and cheese. Food Chem. 197:622-633. https://doi.org/10.1016/j.foodchem.2015.10 .133 .

Valenti, B., G. Luciano, M. Pauselli, S. Mattioli, L. Biondi, A. Priolo, A. Natalello, L. Morbidini, and M. Lanza. 2018. Dried tomato pomace supplementation to reduce lamb concentrate intake: Effects on growth performance and meat quality. Meat Sci. 145:6370. https://doi.org/10.1016/j.meatsci.2018.06.009.

Van Soest, P. J., J. B. Robertson, and B. A. Lewis. 1991. Methods for dietary fiber, neutral detergent fiber, and nonstarch polysaccharides in relation to animal nutrition. J. Dairy Sci. 74:3583-3597. https://doi.org/10.3168/jds.S0022-0302(91)78551-2.

Vasta, V., M. Daghio, A. Cappucci, A. Buccioni, A. Serra, C. Viti, and M. Mele. 2019. Invited review: Plant polyphenols and rumen microbiota responsible for fatty acid biohydrogenation, fiber digestion, and methane emission: Experimental evidence and methodological approaches. J. Dairy Sci. 102:3781-3804. https://doi.org/ 10.3168/jds.2018-14985.

Waghorn, G. 2008. Beneficial and detrimental effects of dietary condensed tannins for sustainable sheep and goat production-Prog- ress and challenges. Anim. Feed Sci. Technol. 147:116-139. https:/ /doi.org/10.1016/j.anifeedsci.2007.09.013.

Zannoni, M., and S. Annibaldi. 1981. Standardization of the Renneting Ability of Milk by Formagraph. Pt. 1. Scienza e Tecnica Lattiero-Casearia.

Zhang, J., X. Xu, Z. Cao, Y. Wang, H. Yang, A. Azarfar, and S. Li. 2019. Effect of different tannin sources on nutrient intake, digestibility, performance, nitrogen utilization, and blood parameters in dairy cows. Animals (Basel) 9:507. https://doi.org/10.3390/ ani9080507.

\section{ORCIDS}

R. Menci $\odot$ https://orcid.org/0000-0001-9967-8986

A. Natalello $\odot$ https://orcid.org/0000-0002-9802-2501

M. Caccamo ㄴ https://orcid.org/0000-0003-3500-0724

V. Niderkorn (ํ) https://orcid.org/0000-0002-4631-7623

M. Coppa (ㄴ) https://orcid.org/0000-0003-2073-0599 